\title{
A new social physic: The sociology of Gabriel Tarde and its legacy
}

\section{Sergio Tonkonoff}

National Council of Scientific and Technological Research, Argentina

\begin{abstract}
This article aims to present a reconstruction of Gabriel Tarde's micro-sociology in order to highlight its current relevance. The author of the article attempts to show that its distinction lies in taking the immense diversity of small social interactions as a starting point for the analysis of both face-to-face situations and large-scale institutions and social processes. Here the social field is described as made up of multiple propagations of desires and beliefs that spread from one individual to other, taking countless directions, interfering with each other, forming networks, and escaping them in search of new connections. The author attempts to show, also, that this point of view doesn't deny the existence of social systems but understands them as open ensembles of immanent and partial relationships of collective beliefs and desires. This is why Tarde may be considered the founder of a molecular or micro-physical sociology.
\end{abstract}

\section{Keywords}

Cartographic knowledge, micro-sociology, polygenesis, social ensembles, Gabriel Tarde

How to read Tarde today and why: these are elemental questions we need to ask in the face of the fact that this thinker has returned after being absent for so long. Should we agree with his adversaries and interpret him as an imprecise and speculating psychologist (Durkheim, 1905), convinced that the individual is the first and last stone of the social building (Bouglé, 1905)? Or should we adhere to those who vindicated him as a social

\footnotetext{
Corresponding author:

Sergio Tonkonoff, National Council of Scientific and Technological Research, Av Rivadavia 1917, Ciudad Autónoma de Buenos Aires, 1033, Argentina.

Email: tonkonoff@gmail.com
} 
psychologist who only knew individual consciences (Blondel, 1928), or as a precursor of the methodological individualism (Boudon, 1971)? Certainly, there are statements in Tarde's works that could confirm these interpretations. If we add to this the constant concern for singularity expressed by this outsider of the academic system, who became a famous professor of the Collège de France and was then forgotten by French posterity, maybe we could accept the rushed, agonistic, or erroneous judgments that sent him into oblivion. But by doing so, the essential would be lost: for Tarde, everything is a society, including the individual.

In 1968, after more than half a century of being the object of marginal and sporadic attention, Tarde's pluralist ontology and sociology were reawakened from a new perspective, with the criticism of structuralism and the publication of Deleuze's Difference and Repetition - a title that suggests a tribute to this neglected and original thinker. In this book, Tarde is presented as a creator of a philosophy of difference, as the one who has gone furthest with the treatment and classification of the opposition category, and as the creator of a micro-sociology that rejects sociological explanations based on impersonal givens or on the ideas of great men, replacing them with 'the little ideas of little men, the little inventions and interferences between imitative currents' (Deleuze, 1994: 158). In A Thousand Plateaus (1980), Deleuze's tribute is even more explicit, and this micro-sociology operates as a powerful driving force of political and social schizoanalysis - that is why it is useful to read, for example, the chapter 'Micropolitics and segmentarity' in parallel with Tarde's (1901b) essay 'The opinion and the multitude'. A third important reference is Deleuze's book about Foucault, published in 1986. In that study, a still unaccomplished task is outlined: to compare Foucauldian micro-physics of power with Tarde's micro-sociology. And that is because the latter's was concerned with the propagation of 'small ideas of small men, a signature of a bureaucrat, a new local custom, a linguistic deviation, a visual twist', while micro-physics of power attributed a fundamental role to 'minuscule inventions' related to the production of a power that has nothing to do with structures but instead with singular points of exercise (Deleuze, 1988: 81).

This Deleuzian restoration has been the beginning and the orientation of a series of developments in which Tarde's micro-socio-logics appear at the center of an emerging paradigm: one that postulates society as an assemblage or dispositif. The first great implementation or mise en œuvre of this new paradigm was, as we can see now, Discipline and Punish (even though Tarde's name is not mentioned once). There, Foucault characterizes the exercise of power in its disciplinary modality as a kind of 'Christopher Columbus's egg' of the political domain. An invention that should not be understood as a single and sudden creatio ex nihilo, but as 'a multiplicity of often minor processes, of different origin and scattered location, which overlap, repeat, or imitate one another; support one another; distinguish themselves from one another according to their domain of application; converge; and gradually produce the blueprint of a general method' (Foucault, 1979: 138). These disciplines would then be a form of knowledge/power that emerged from diverse technological discoveries. By being intertwined in flexible networks, and by spreading throughout the multiplicity of the social body, they form a disciplinary society. Soon we will see how strictly Tardean this conceptualization of the social logic of power really is. 
More recently, Bruno Latour and Maurizio Lazzarato also found in Tarde's work the starting point for new formulations about social reality and the ways to comprehend it. Latour (2005) considers Tarde as a precursor of the actor-network theory developed in his book Reassembling the Social. One of the objectives of this theory is to question the existence of a specific phenomenon called society. It also questions whether the social can be taken as an explanatory variable or as an independent factor. Based on Tarde's (and Deleuze's) theoretical framework, Latour suggests a sociology that replaces the notion of society with the notion of association and derives its explanations from the activity of following the connections existing between heterogeneous elements (ideas, organizations, objects, places) - turning sociology into a sort of 'asociatiology'. In Latour's (2002) opinion, Tarde was a theorist of networks avant la lettre, i.e. before the technological globalization and the computer science breakthrough. Tarde would also be someone who thought the nature-culture division to be irrelevant to the comprehension of human interaction and considered the micro-macro distinction to be an inadequate response to the question of how society is created. Latour (Latour and Lépinay, 2008) understands that the fate of social sciences would have been different - more fortunate - if the two volumes of Tarde's Economic Psychology had received more attention than The Capital, or if his Social Laws had taken the place of Durkheim's The Rules of Sociological Method.

Lazzarato (2006), for his part, considers Tarde to be the creator of an ontology of multiplicity, indispensable for the development of new lines of thought about society and politics. In this sense, Tarde would participate in the anti-Hegelian family that from Nietzsche to Deleuze - passing through William James and Bergson - shows a departure from philosophies of the subject and social theories that sealed the modern age. In Puissances de l'invention (2002), his sociological approach is presented as an alternative to the classical opposition of individualism and holism, because of his understanding of the production and composition of the social world as based on the double mechanism of repetition and difference. He is also considered an alternative to Marxism and the classical political economy, as he explains value creation not in relation to economical production and the accumulation, but instead to the dynamics of the events or inventions.

All this is to say that we might be witnessing the configuration of a new sociological paradigm (new syntax and new concepts), in which Tarde officiates as a major founder. And that probably all that is contemporary in this nineteenth century thinker depends on these kinds of readings. In any case, this is the specific context in which Tarde comes to us. Since his death in 1904, his worldwide influence - from the First Chicago School to the Latin American sociology - had been diminishing until having almost disappeared. It was in the late 1980s that some of his most important works started to be reprinted in France, and it was only in 1999 that Éric Alliez - a disciple of Deleuze and one of the creators of the journal Multitudes - directed the publication of Tarde's complete work. In 2001, Multitudes dedicated a monographic number to this rebirth titled Tarde intempestif, a Nietzschean allusion that might refer more to the context in which Tarde is reintroduced than to the author himself.

This is one of the reasons why some historians of the social sciences have come to argue that we are suffering an epidemic called 'tardomania', and why they consider it unjustified (Mucchielli, 2000). They reject the nature of this rediscovery by describing it 
as philosophically slanted, hagiologically motivated, and historically anachronistic. They also emphasize Tarde's lack of scientific rationality considering his thinking method to be metaphysic, literary, and even journalistic, and challenging his limited or null disposition to the empiric validation of the hypotheses he formulates. It is clear that this criticism follows a tradition: one that considers Tarde as a negative referent, a suggestive, perspicacious, and even sympathetic model of all that has to be avoided to build a science of the social. Such a tradition deserves the name Durkheimian.

\section{Elemental sociology}

Durkheim's project was based on the attempt to found sociology as a positive science of social facts. In his opinion, this science would only be possible by establishing its own object of study as well as its own explicative principles. Therefore, he strived to define, in the first place, society as a specific entity separating it from the individual domain, sustaining that both belong to different levels of reality (Durkheim, 1982). That is, he endeavored to give society an ontologically and analytically irreducible dimension, considering it as a system of collective modes of acting, thinking, and feeling: a sui generis reality with logical priority with regard to individual actions, which could (and should) be described and explained excluding all reference to (individual) psychology. This approach led him to understand society as a supra-individuality with a life of its own, characterized by its exterior condition and its coercive nature with respect to individuals that, nevertheless, are its necessary condition. In Durkheim's opinion, society can only be the object of sociological research as a totality, an abstraction made from its individual variations.

Tarde, on the other hand, does not start by viewing society as a pre-existing domain, distinct from the elements that compose it, and for him it is a scientific prejudice to treat unity, structures, and hierarchies as the beginning and end of everything. He stated that 'heterogeneity, not homogeneity, is at the heart of things' (Tarde, 1903: 71). He believed in the multiple, heteroclite, and heterarchical nature of both the natural and social world, and stated that science has to somehow take into account this fact. Like Durkheim, he tried to produce a scientific discourse under the name of sociology and attempted to establish its relative autonomy. But in his opinion, instead of starting by analyzing the actual structure of social objects, this science should start by reconstructing the diverse ways in which these structures are produced (that is what Tarde calls polygenesis). He also stated that instead of separating society from the individual, sociology should draw on the distinction between three forms of inter-psychological or inter-mental relation: imitation, invention, and opposition.

Tarde (1903) called imitation a type of social bond in which someone offers him or herself, voluntarily or involuntarily, as a model, and someone else, consciously or unconsciously, copies him or her. It is a form of relationship in which someone influences, suggests, or orders and someone else is influenced, accepts, or obeys. In his words, it is 'the action at a distance of one mind upon another, an action which consists of the quasiphotographic reproduction of a cerebral image upon the sensitive plate of another brain. ... By imitation I mean every impression of an inter-psychical photography, so to speak, willed or not willed, passive or active' (Tarde, 1903: 14). It is an asymmetrical, 
contingent, and reversible relationship that, each time, can or cannot be reproduced as well as reversed - in which case, the model will become a copy. It is also a 'contagious' mode of interaction able to repeat itself, spreading from one individual to another, homogenizing the spaces in which it has been displayed, or rather producing a particular kind of spaces: spaces of similarities and regularities, of social reproduction. In consequence, the social bond would be produced as follows: a way of acting, feeling, or thinking of one individual that is transmitted to another; this individual will repeat the behavior, serving as an example to a third person, who, in turn, will also be copied. This is what Tarde calls ray flow, wave, or imitative current. When currents of new examples arise and disseminate they take the form of fashions, if they take roots and establish themselves they become traditions (Tarde, 1903: xxi).

There would be no problem with calling this perspective 'atomistic', as long as one recognizes that society is entirely divisible into molecules and atoms, and that, in turn, these atoms can also be decomposed. In short, individuals are not irreducible and compact elements here. Rather, they are open monads almost entirely made up of beliefs and desires. These are the very particles (subatomic, it could be said) that form the internal world of individuals. But also - and this is key - they form the micro-physical matter of which social life is made. This life is nothing but the flowing, converging, clashing, and deferring of currents of convictions and passions that compose and decompose society and its subjects. Even though Tarde calls these currents inter-psychological or interindividual, this should not confuse us. An individual is, most of all, a passage and sedimentation zone of social flows that are repeated in him (or her) in the form of judgments, memories, wills, and habits. It is in social interaction, through the imitation of others, that a psychic unit of relative coherence and determination starts to emerge where there used to be (and still is) a biological, 'metaphysically' excessive and porous monad. ${ }^{1}$ Individuals imitate, but what is important is what is imitated. What is imitated are always ideas and wishes, faiths and passions: these are the elemental generative forces of the social field. ${ }^{2}$ That is why, at this level, society is 'the organization of imitativeness' (Tarde: 1903: 70), and the same can be said about groups and even individuals.

But, where do these imitatively propagated beliefs and desires come from? What is the genesis of what offers itself as a model? Tarde's answer to this issue is focused on the concept of invention. All inventions are, in a sense, individual, but the individual is not the main category here, nor is it the constituent element: any social novelty occurs in someone who, however, is not exactly its origin. Moreover, invention does not mean rootless creation, but instead co-adaptation or composition of a pre-existing series of examples. ${ }^{3}$ It can happen that some of the imitative currents that pass through and constitute an individual subject combine themselves in an unprecedented manner. Only in this way, will a simple or complex, theoretical or practical, scandalous or silent innovation take place. The innovator is the locus of an unexpected combination of pre-existing premises that introduces new differences (new beliefs and desires) in the social world. If the invention is imitated, it will act as a focus whose rays will modify the disposition of the social space in which they propagate. Thus, the social field would be woven by countless repetitions of countless inventions imitatively propagated at different times, with different directions and scopes. Thus, 'the strength and extent of social bonds between associates are due to the number and importance of the types, of the clichés, of 
the models, which are common to them, i.e., of the inventions, of both ancient or recent individual initiatives from which derive, by imitative propagation, their manner of speaking - even when they contradict each other - , their ways of praying or making sacrifices to their gods - even when they anathematize each other - , their ways of working - although in competition - , their ways of understanding duty - even if in duty they kill each other' (Tarde, 1898a: 42).

However, not every invention is effectively imitated. And this is because at each time and place there are multiple inventions that compete against each other and previous ones that are reproduced as customs. ${ }^{4}$ Each invention encounters exemplar events and imitative flows on its path that can either complement or neutralize it. Such neutralization, which for Tarde (1897: 15) can only be provisionary, is at the core of relationships of opposition - relationships that are also part of the social field as he understands it.

Tarde (1897: 223-236) states that polemics, competitions, and wars are (massive) social phenomena of opposition; and that also individual hesitation is a (infinitesimal) phenomenon of this kind. The indecision of adopting or rejecting a new word, dress, trade, profession, or political party refers, in his opinion, to the distinct imitative vectors that intercept and antagonize each other in a single mind. This very micro-social process takes place every time someone is exposed to influences that, radiating from near or far, contradict his/her habits. Once this 'internal' fight is over, once a particular course of action, judgment, or passion has prevailed, the individual can oppose others because she or he considers them to be bearers of the rejected option. Every social space is then populated by multiple conflicts, countless (although different in content) battles between opposite imitative flows that fight to prevail. Some of these conflicts can also imitatively propagate themselves, forming belligerent groups. The major social conflicts take place when individual hesitations about the point of dispute are decided, and this decision starts to disseminate. By contrast, the spread of the doubt itself will produce a general state of skepticism on its area of influence (Tarde, 1898b: 37).

However, Tarde warns us that we shouldn't think oppositions occur when radically different flows face each other. Radical differences cannot confront each other. Opposition is a type of social relation defined as 'a very singular kind of repetition, in which similar things are willing to destroy each other in virtue of their very similarity' (Tarde, 1898b: 70). That is, two social currents clashing not because of being completely different but because of being 'counter-similar'. ${ }^{5}$ The conflicting terms are mutually blocked forces as they converge on the same object: some reinforce and others deny the same belief, opinion, feeling, or practice. Tarde, as well as Simmel (1955), clearly saw that conflict doesn't constitute a paroxysm of separation between individuals and groups, but tends to be a (very intense) form of social bonding. He also believed that oppositions, rather than constituting the driving force of socio-historical change, produce a certain form of balance or stoppage in the development of the social process. For Tarde, true transformations in the multi-centered process of social communication do not come from any form of fights - not even the most violent ones. Violence is the result of an exacerbation of counter-similarities, the physical effect of the intensification of an opposite dynamic. ${ }^{6}$ Beyond the threshold of functionality favorable to the reproduction of the oppositional system, this dynamic can produce the destruction of a state of affairs, but not its transformation. Tarde (1902) claims that only inventions are able to interrupt the game 
of repetitions and counter-repetitions that reproduce the societal organization and give way to something new.

\section{Polygenesis}

Put in these terms, the social field can be described as a collage like space made of multiple propagations of ideas and passions reproduced from one individual to another; a constellation of changing volitions and convictions that spread themselves in countless directions, interfering with each other, adapting among themselves, forming networks, producing institutions, groups, and individuals, and escaping from them in search of new connections. That is why this micro-sociology is, after all, a science of communications. It is a tripartite science composed not only of an elemental sociology, but also of a social logic and a social teleology. Elemental sociology, as mentioned before, studies the basic modalities of interaction produced both at a distance and in face-to-face situations. In other words, it focuses on the way in which collective beliefs and desires emerge by invention, are propagated by imitation and neutralize each other by opposition. That is why Tarde's first objects of study were not major representations, social classes, or state apparatus, but microscopic processes of repetition, counter-similarity, and differentiation, present in multitudes, small groups, public opinion, conversation, rumor, and economic exchanges. This also explains why his sociology does not tolerate abstractions such as 'the' society (or even 'the' individual), or explain the processes of social transformation and the states of equilibrium in terms of structures and factors. As we saw, all social phenomena, all current forms of acting, feeling, or thinking, were once born of a spectacular or discreet example, and spread themselves as fashions, to finally become established institutions, and repeated as custom. Such is the specific manner by which both individual and social homogeneity is produced, where there used to be a dispersion of heterogeneous desires and beliefs. And such is the Tardean sense of social history: the transition from heterogeneous to homogeneous, from small to large, from plurality to unity, and from local to global. But, as we will see in detail below, those units and uniformities are always partial and continually overflowing with disjunctions and differences. Therefore, such history, the history of the global socialization of humanity, is endless: it is always launched in new directions by those somehow non-historical and supra-societal events called inventions.

Logic and teleology, on the other hand, are dedicated to mapping and measuring the distribution and organization of the currents of convictions and wills that produce (and are produced by) the inter-mental action of individuals. The first follows the forms of composition of collective desires (or the 'social will'), while the second deals with the articulation of collective beliefs (or the 'social intelligence'). But a true social science of logic must include the study of the illogical; and a knowledge of social teleology must take into account 'not only the agreement of means and ends, but also the disagreement of the ends between them' (Tarde, 1895b: 137). And, given that will and intelligence are two components of every social current, the next step is to discover how the collective judgments are intertwined or co-adapted with collective purposes in the formation of institutions, i.e. those large societal phenomena that are the habitual objects of (macro) sociology. 'Is it not clear that chaos, historical inconsistency, is the fermentation from 
which those wonderful and original systems of ideas and acts, of acts or ideas, were laboriously built: the language, with its grammar always more or less rational; religion, with its rudimentary or refined theology; the political constitution, a code or codes, sometimes the incarnation of reason itself such as the Corpus Juris, etc?' (Tarde, 1895b: 130). At this point, an additional task is to know which of those dimensions prevails, setting the tone for the phenomenon in question. For Tarde (1893), beliefs dominate in the formation and transformation of languages, religions, philosophies, and sciences, while desires dominate in the formation and transformation of laws, customs, arts, and industries.

This sociology is then a cartographic or diagrammatic form of knowledge. It has to take into account the communication, composition, systematization, institutionalization, and destitution of collective assertions and negations, attractions and repulsions, submissions and resistances that weave the social network. But if elemental sociology is concerned with the formation of social tissues, logic and teleology has to deal with the formation and functioning of social bodies. In both cases, the first step to studying any social phenomenon - global or localized, stable or critical - is to find a beginning. But, for Tarde (1895a), such a beginning is always located in media res, for an invention adapts imitative rays previously acting in the social field, generating an unprecedented conjunction, and giving rise to a new start. Here, both constitution and destitution of any 'social fact' depend on the communication of collective beliefs and desires; and such a communication always has a singular irradiation point. Even when a way of acting, thinking, or valuing might institutionalize or collectivize itself in a seemingly impersonal manner, there is an individual, or rather a particular type of individuation, in its origins and successive transformations. Tarde (1898b: 55) wants us to decompose the reifying notions of our habitual vocabulary - science, moral, law, economics, nation, etc. - by reconstructing the specific processes of emergency and dissemination that those notions only capture in their results. These abstract terms don't allow us to see what has actually happened. They tend to hide the precise inventions, imitations, and oppositions, after which an example becomes anonymous, repeating itself as if it had no origin, or as if this were indefinite.

This means, among others things, that we need to understand the individual and the society as that which must be explained and not that which must be assumed - and the same is true for the intermediate subsystems and international associations. To account for all these social entities it is necessary to reconstruct the histories converging within them, which grant them their actual physiognomy. Namely, the histories of localized inventions, their propagation range, the resistances they encountered, the conflicts they caused, the truths they displaced, the compositions they interweaved, the new world (big or small) they generated, and which now appear in front of us as a compact and naturalized - true - matter. That is why, Tarde wrote: 'instead of explaining everything by the alleged imposition of an evolution law that requires that the global phenomena reproduce and repeat themselves identically in the same order, rather than explain, therefore, the small by the big and the detail by the whole, I explain the similarities of the ensemble by the assembling of small elementary actions, the big by the small, the large by the detailed. This way of looking at the subject brings to sociology the same transformation that has resulted from the introduction of infinitesimal analysis in mathematics' (Tarde, 1898b: 22). 
Tarde (1895a) formulates the polygenesis as a major mapping method of the sociological approach - a method, we now see, which is notably similar to Foucault's genealogy. ${ }^{7}$ This poly- or hetero-genetic method allows us to notice that everything that from a distance appears to be a continuous volume made of a single piece is actually a multiplicity. It allows us to wonder how these multiplicities constitute themselves as more or less enduring units, which (on a certain level and from a certain point of view) are systems of structures and functions. And it also allows us to wonder, what kind of systems are they?

\section{Social ensembles}

Tarde's answer to these questions is that every social unit must be understood as an ensemble, compound, or configuration of previously disperse flows of desires and beliefs. A composition that increases or decreases as new currents join it and as its riverbeds increase or decrease its quantum. The form, stability, and duration of an ensemble refer to the associative interaction of imitative currents that, by co-adaptation, take on a certain structure and a relatively coordinated set of functions. As mentioned, these coadaptations are logical as well as teleological: they systematize beliefs and purposes, convictions and desires.

For Tarde, also on this level, sociology must be a cartographic activity. Following his method, to characterize any social system we have to identify the specific manner in which its elements have been articulated or disposed. We also have to measure the coherence of each disposition and the degrees of cohesion that connect its different parts to each other. In addition, we must describe its internal morphology, the direction of its flows, its degrees of intensity (rises and drops), the positive or negative nature of its charges, as well as the inputs and outputs (regular or irregular) that nourish its economy, and its relations with other ensembles. This has to be done every time, for each social ensemble studied, for they are culturally, historically, and locally embedded.

Nevertheless, this nominalist tendency doesn't prevent Tarde from establishing a series of common characteristics for all social composition. First of all, they are always composed of immanent relationships, of bonds made of desires and beliefs, that don't refer to any external substance or structure that gives them a basis, meaning, or direction beyond their own disposition. Not biology, reason, or economy, can ultimately act as the foundation of social dynamics and organizations. The second characteristic is that these immanent relations between desires and beliefs have a contingent nature with regard to both their form and duration. That is to say, they can be produced and stop being produced every time. They are contingents not only at the moment of their invention but also when the circuit of their reproduction is already installed. And this is mainly because (the third characteristic) the assembled structure or system never totalizes the elements that compose it. In this sociology, the whole is always smaller than the sum of its parts. Here, each part establishes a fragmentary or partial bond with the other elements, to form the unit they always exceed. On the other hand, each part can participate in different ensembles at the same time, as well as avoid all of them. According to Tarde, the social tissue always both composes and overflows the social organs - that is why Deleuze (2007: 135), his best inheritor, would say that 'in a society, everything flees'. 
There are no exhaustive and exclusive relations in the Tardean social world. Each element itself is a compound exceeded by connections and flights that are not included at the level of its unity. To say that a system doesn't totalize its own components means that each component has its own activity and that it acts (when it does) in association with different ensembles - to which it belongs according to different modalities and diverse degrees. It also means that each element is able to modify some of its relations without changing them all. Finally (the fourth main characteristic), not only does such an ensemble or system not totalize its components but neither can it be entirely complete or absolutely coherent. In Tarde's words: 'The aspiration of a social state to be an entirely logical system with the elements that compose it, is never satisfied more than in part, and we see why: this state was not born outright, in a single block, but was formed slowly by intermental accidents, by cross-linked imitative radiation and it continues reproducing with incessant changes, by the exchanges of examples and ideas with the surrounding societies, formed, also, by incomplete fusions of contagious individual influences' (Tarde, 1901a: 198). There are systems, but they will never fully stabilize themselves by defining either the meaning or the desires they hold, for they are always subject to constant variations in the intensity of their constitutive flows, as well as in the degree of connection and coordination of their parts.

Therefore, for this micro-sociology, the concepts of society and the individual can still be legitimate notions of sociological discourse if they are understood as open ensembles of immanent, contingent, and partial relationships of beliefs and desires in continuous change, and if their constitution is understood as an event itself. In both cases, some of the multiple currents that form the polymorphous field of social life have come to constitute, through precise co-adaptations, systems of judgment (logic) and systems of purpose (teleology), without ceasing to differ or interfere in other aspects.

Thus, every social unity would be an interval between two dispersions, and its relative consistence result from the association of the fleeing elements that exceed it. Any social formation constitutes a system that tends toward coherence and completeness without ever reaching it, an unstable and temporary point of assemblage of some of the many currents of passion and faith that constitute social life in its exuberance and diversity.

According to this, nations, states, and economic organizations, as well as morals, religions, and ideologies, are not structures that would constrain their components from the outside, but are instead inter- or trans-individual ways of doing, feeling, and thinking, logically and teleologically articulated. Closely examined, that which we call an 'institution' is a network linked to other networks. Its configuration doesn't depend on entities or processes that, from an infrastructural or transcendent exterior, would determine its form and allow for its stability. For Tarde, not only the origin but also the duration of (economic, cultural, political) macroscopic regularities should be sought in the infinitesimal repetition of a certain kind of activity - repetition that itself implies infinitesimal variations.

One major consequence of this is to see the stable states of social matter as depending on a large number of simultaneous elemental activities, and to understand that this stability is constantly undermined by little and countless transformations, at the level of the elemental repetition that produces it. If any social system is the result of the composition of desires and beliefs reproduced from one individual to another - or better, from one 
portion of an individual to a portion of another -its very form of existence implies change and movement. Even the best structured and enduring religion, form of government, or mode of production suffers in every individual repetition (and there is no other form of life for a social system) an infinitesimal variation that inevitably will lead it to its imbalance and alteration. If one takes any statistical regularity paying attention to its coefficient of variation instead of its average, one will see that there is no social ensemble free from the more diverse and constant (micro-)mutations. Such a micro-sociological process is by itself capable, even at its slowest rhythm, of modifying the global characteristics of the system in question, once a certain threshold is exceeded.

Following this line of thought, one could think of a network of networks, and call this composition of superior level 'society'. The key, however, is not to invoke with this word the image of a complete, organized, and functional body (an organism); nor to find a totality constituted by a single major class contradiction that determines all its instances. Instead, what will emerge is a vast and dense weave of relations marked at countless points by disjunctions that split it and oppositions that interrupt it. Society, then, will be an assemblage of numerous assemblages coexisting with an even larger number of (social) relations that are not included in it. This perspective also allows Tarde to state that, as we pass from a certain level of composition to a superior one, we go from the most complex to the most simple and stereotypical. Therefore, societies present a type of organization simpler than that of its components (networks of an inferior level of generality). To sum up this thesis, Tarde (1892: 365), with his characteristic eloquence, points out that an anthill is incomparably less complicated than an ant itself.

This is the peculiarity of this molecular sociology: taking the immense diversity and complexity of the smallest - which is also the most undetermined - as a starting point, postulating that the heteroclite and heterarchical are the beginning and the end of the socially structured world, and understanding that the macro is always more schematic and more standardized than the micro. In short, it is characteristic of this kind of sociology to show that society doesn't comprehend the totality of the social.

If ensemble means co-adaptation, and different social ensembles can co-adapt between them, then a society is a co-adaptation of a superior level of ensembles partially articulated. But this means that the believing and desiring forces that constitute it always go beyond its control, establishing local, regional, and/or international connections. This also means that inside and next to this irregular and fragmented composition that we call society there can exist: (a) systems that are partially or wholly opposed to it, (b) other non-adapted systems, as well as, (c) differences that are not adapted or opposed to anything. In other words, all society is traversed and exceeded by some forms of thinking, feeling, and acting which are para-societal; by others which are criminal, immoral, or anti-aesthetic (because they contradict the evaluative canon established by this net of networks); and by parallel worlds, released, to a greater or lesser degree, from societal determinations.

\section{By way of conclusion}

Toward the end of the nineteenth century, the controversy between Tarde and Durkheim i.e. the confrontation of different possibilities for the sociological discipline embodied in 
these two particularly capable individuals - was a conflict whose resolution would have foundational consequences for social sciences and its division of labor. ${ }^{8}$ Durkheim's institutional victory, and his later official establishment as a founding father of French sociology, strongly delimited this field of knowledge through the exclusion of the Tardean points of view. This was a milestone in the establishment of the separation of sociology from philosophy, psychology, biology, and art; the exclusion of the question for the individual; and the establishment of institutions as objects of study, if not exclusive, at least privileged. Since that time, the mainstream of the discipline would assume a perspective of the social world that can surely be called macro-physical. Following this approach, important regularities were found behind the apparent wandering and diversity of individual behavior. Subsequently, laws and models were formulated to describe and explain those regularities. But, immediately, the generalizations made in this context were substantialized by considering certain global entities (such as the collective conscious or the social system) as causes of the repetitions, uniformities, and stabilities that were found. The results of social life were hypostatized in different pairs whose poles would then be studied separately: society/individual, social representations/individual representations, state/civil society, structure/agency. For this reason, those social manifestations that do not seem to depend on these total entities tended to remain outside, or in the margins, of the visibility of the theoretical dominant traditions. Issues such as the social logic of masses or the dynamics of small groups - along with their corresponding forms of (de)subjectivation - were considered secondary, exceptional, para-social, or even pathological phenomena: residues of society and its sciences.

At some point in time, the rule of sharp separation between different kinds of knowledge of the social field and the privilege of the macro-social objects was no longer adhered to. Sociology was faced with the necessity to reconnect with the other social sciences, and to intensify its dialogue with philosophy and, to a lesser extent, with art. On the other hand, societies are no longer understood as closed or organic wholes. This applies, at least, to those who discovered that 'the' society - or, in other words, the functional, structural, or dialectic totalization of the social relations - has never existed. At the same time, those phenomena that were invisible to systematic theories, and marginal to the organized societies, are revisited. And that is because it seems to be the moment of a tendential deployment of post-societal logics: those that question the identity of the social ensembles that represent themselves as nation-states, promoting the pluralization of forms of sociability and the increasing re-enchantment of the world. These social logics are starting to be analyzed with notions such as multiplicity, belief, desire, event, flux, network, and assemblage. These notions are usually identified with post-structuralist thought, and today form part of the standard vocabulary of social sciences. Nevertheless, their Tardean affiliations are generally unknown.

This unawareness increases a typical risk of the 'post-societalist' analysis: to fall into the aporias of dissemination - the reverse danger of the substantialist fetishism that haunted traditional sociology. And that is because the analysis of the emerging social dynamics of networks, multitudes, publics, tribes, and so on, with an exclusive emphasis on the dispersion that is characteristic of them can become lost in the mirror game it describes. In other words, the one-sided emphasis on the fluidity of late-modern social phenomena carries the risk of overlooking, at the theoretical level, the existence of relative systematizations 
without which no identity or meaning, precarious as they can be, would be possible. The correlative risk, at the political level, is to ignore the constant recoveries by the semiotic capitalism of the liberated diversity through the crisis of modernity, and its re-codification in terms of what Scott Lash (1990) called postmodernist re-stabilization.

One remarkable value of Tarde's work is that it can help us to prevent the (modern) societalist hypostasis as much as the (postmodern) aporias of dissemination. And that is because his conceptual syntaxes reject the temptations of the reification of social structures and functions, while at the same time permitting the avoidance of the absolutization of its polar and imaginary opposite: the completely non-structured social dispersion. Even when Tarde considers the plurality of the social field as an irreducible theoretical beginning - and as an equally irreducible ethico-political end - he is always concerned with the ways in which social unities and systems are composed.

The current re-encounter of social sciences and philosophy with Tarde as a thinker of multiplicity shouldn't make us lose sight of the fact that he pointed out not only the ways in which the social field flees from society, but also illuminates the forms of compositions of the multiple collective flows. In short, he allows us to state that society can still be a genuine object of sociology - although maybe not the most important - on the condition that it is de-sustantialized and de-totalized, treated as an assemblage. The remarkable feature of Tarde's sociology lies in its capacity to take into account the regularities, similarities, and units while preserving the rights of multiplicity and difference. This perspective allows for the comprehension of the social not with mechanical, organic, or dialectic models but instead with hydraulic, electromagnetic, and probabilistic ones. That is to say, with the belief that the real agents and the real actions are infinitely varied and infinitely small (Tarde, 1999); or that social reality is so irreducibly diverse that we can characterize it as 'ant-like' (Tarde, 1898a). Tarde leads us to think of society in terms of communication networks that inductively produce an 'overall effect', plagued by conflictive oppositions, drifts, and escapes. This is an invitation to go from a panoramic treatment of society to the detailed exploration of the elemental modes of production, reproduction, and metamorphosis of social assemblages; an incitement to pay attention to sub-representational flows and varied repetitions, molecular connections and disjunctions in which social phenomena are originated, transformed, and, eventually, diluted. Tarde inaugurates a sociological paradigm in which the displacement from the macro- to micro-perspective is not only a change of the scale from global structures to inter- or trans-individual interaction, but also, and above all, a conquest of a new point of view for the general comprehension of an epoch: a theoretical syntax apt to describe and analyze the interpersonal bonds in its local details as much as the larger social systems in its formation, developments, and transformations.

\section{Acknowledgements}

I would like to thank the two anonymous reviewers and the editor for the time, insight and dedication that they gave to this article. Thank you very much.

\section{Funding}

This research received no specific grant from any funding agency in the public, commercial, or not-for-profit sectors. 


\section{Notes}

1. Tarde was a subtle and creative reader of Leibniz's Monadology. To give coherence to a monadic-made world without God, Tarde (1999) felt obliged to open the Leibnizian monads and to spiritualize them. On the Leibniz-Tarde relationship see Alliez (1999), Lazzarato (1999), and Clet (2001).

2. 'My ideas on imitation could not be separated from my thoughts on the beliefs and desires: they form a block. Not satisfied with the words, I do not accept the imitation but the imitation of something, and the substance, the force transmitted from brain to brain by imitation, is a belief or a desire' (Tarde, 2000: 236).

3. 'Whatever be the category to which it belongs, an invention has the characteristic of being always an intersection of imitative rays, an original combination of imitations' (Tarde, 1902: 568). See also Tarde (1898b: 51-65; 1903: 140-145).

4. To answer why some inventions are imitated and others are not, Tarde (1903: 154-173, 194213) formulates some 'logical' and 'extra-logical' laws. See also Katz (1999).

5. Tarde (1897) distinguishes three types of oppositions: of series, of degree, and, most importantly, of sign (formed by two forces going in opposite directions on the same line).

6. According to Tarde, violence is the result of a passionate orthodoxy, an intensely invested dogmatism that is stronger the more it homogenizes the group. This theory of violence as the paroxysm of opposition might be construed from Tarde's text $(1892,1893)$.

7. It is remarkable that almost every commentary on the concept of genealogy in Foucault refers exclusively to its Nietzschean filiation. The obligatory quotation here is the essay 'Nietzsche, genealogy, history' (Foucault, 1980). However, if we consider that in Discipline and Punish, Foucault (1979) explicitly declares his intention to make a genealogy of the modern soul, one only needs to recapitulate the development of this book to see that the genealogic operation is realized on the basis of a consistent use of Tarde's basic series: multiplicity-inventiondiffusion-apparatuses (dispositifs).

8. On the Tarde-Durkheim debate see Lukes (1985), Candea (2010), and Vargas (2000).

\section{References}

Alliez É (1999) Tarde et le problème de la constitution. In: Tarde G, Monadologie et Sociologie. Paris: Les Empêcheurs de Penser en Rond, pp. 9-32.

Blondel C (1928) Introduction à la psychologie collective. Paris: Armand Colin.

Boudon R (1971) La Crise de la sociologie. Questions d'epistémologie sociologique. Paris: Droz. Bouglé C (1905) Un sociologue individualiste: Gabriel Tarde. Revue de Paris 10: 294-316.

Candea M (ed.) (2010) The Social after Gabriel Tarde: Debates and Assessments. New York: Routledge.

Clet J (2001) Tarde: une nouvelle monadologie. Multitudes 4(7): 186-192.

Deleuze G (1988 [1986]) Foucault. London: The Athlone Press.

Deleuze G (1994 [1968]) Difference and Repetition. London: The Athlone Press.

Deleuze G and Guattari F (1987 [1980]) A Thousand Plateaus (Capitalism and Schizophrenia, Vol. 2). Minneapolis: University of Minnesota Press.

Deleuze G with Parnet C (2007 [1977]) Dialogues II. New York: Columbia University Press.

Durkheim E (1905) L'interpsychologie de G. Tarde. L'Année Sociologique 9: 133-135.

Durkheim E (1982 [1895]) The Rules of Sociological Method. New York: The Free Press.

Foucault M (1979 [1975]) Discipline and Punish: The Birth of the Prison. New York: Vintage. 
Foucault M (1980 [1971]) Nietzsche, genealogy, history. In: Language, Counter-Memory, Practice, ed. and trans. Bouchard DF and Simon S. Ithaca, NY: Cornell University Press, pp. 140-148.

Katz E (1999) Theorizing diffusion: Tarde and Sorokin revisited. The Annals of The Academy of Political and Social Science 566 (November): 144-155.

Lash S (1990) Sociology of Postmodernism. London: Routledge.

Latour B (2002) Gabriel Tarde and the end of the social. In: Joyce P (ed.) The Social in Question: New Bearings in History and de Social Sciencies. London: Routledge, pp. 117-132.

Latour B (2005) Reassembling the Social: An Introduction to Actor-Network-Theory. Oxford: Oxford University Press.

Latour B and Lépinay V (2008) L'Économie, science des intérêts passionnés: Introduction à l'anthropologie économique de Gabriel Tarde. Paris: La Découverte.

Lazzarato M (1999) Gabriel Tarde: un vitalisme politique. In: Tarde G, Monadologie et sociologie. Paris: Les Empêcheurs de Penser en Rond, pp. 103-150.

Lazzarato M (2002) Puissances de l'invention. La Psychologie économique de Gabriel Tarde contre l'économie politique. Paris: Les Empêcheurs de Penser en Rond/Le Seuil.

Lazzarato M (2006) Multiplicidad, totalidad y política. Nómadas 25 (octubre): 20-29.

Lukes S (1985) Durkheim, His Life and Work. Stanford, CA: Stanford University Press.

Mucchielli L (2000) Tardomania? Réflexions sur les usages contemporains de Tarde. Revue d'Histoire des Sciences Humaines 3: 161-184.

Simmel G (1955) Conflict. In: Conflict and the Web of Group Affiliations. Glencoe, IL: Free Press, pp. 13-123.

Tarde G (1892) Les crimes des foules. Archives d'Anthropologie Criminelle 7: 353-386.

Tarde G (1893) La sociologie criminelle et le droit pénal. Bulletin de l'Union Internationale de Droit Pénal 379-397.

Tarde G (1895a) Questions sociales. In: Essais et Mélanges Sociologiques. Lyon: Storck, pp. $132-158$.

Tarde G (1895b) La Logique sociale. Paris: Alcan.

Tarde G (1897) L'Opposition universelle: Essai d'une théorie des contraires. Paris: Alcan.

Tarde G (1898a) Études de psychologie sociale. Paris: Giard et Brière.

Tarde G (1898b) Les Lois sociales: Esquisse d'une sociologie. Paris: Alcan.

Tarde G (1901a) La criminalité et les phénomènes économiques. In: V Congrès International d'Anthropologie Criminelle, Amsterdam, pp. 197-204.

Tarde G (1901b) L'Opinion et la foule. Paris: Alcan.

Tarde G (1902) L'invention considérée comme moteur de l'évolution sociale. Revue Internationale de Sociologie 7: 561-574.

Tarde G (1903 [1890]) The Laws of Imitation. New York: Henry Holt and Co.

Tarde G (1999 [1895]) Monadologie et sociologie. Paris: Les Empêcheurs de Penser en Rond.

Tarde G (2000 [1897]) Contre Durkheim à propos de son Suicide (manuscrit). In: Borlandi M and Cherkaoui M (eds) Le Suicide. Un siècle après Durkheim. Paris: PUF.

Vargas E (2000) Antes Tarde do que nunca: Gabriel Tarde e a emergência das ciências sociais. Rio de Janeiro: Contra Capa Livraria.

\section{Author biography}

Sergio Tonkonoff holds a PhD in Sociology from Campinas University (São Paulo, Brazil). His research interests include classical and contemporary sociological theory and cultural studies, areas in which he has published in international journals. He has lectured and given faculty seminars in Spain, Brazil, México, and Argentina, and currently teaches contemporary sociological theory at the University of Buenos Aires. 


\section{Résumé}

Cet article a pour but de renouveler la microsociologie de Gabriel Tarde afin de mettre en évidence sa pertinence et son actualité. J'essaierai de montrer que son originalité réside dans la prise en compte d'une grande diversité de petites interactions sociales comme point de départ de l'analyse aussi bien des interactions entre les individus que des grandes institutions et des processus sociaux. Ici, le champ social est décrit comme un ensemble de désirs et de croyances qui se propagent d'une personne à l'autre, qui prennent d'innombrables directions, interférent avec les uns et les autres et forment des réseaux dans le but de les dépasser à la recherche de nouvelles connexions. J'essaierai de montrer que ce point de vue ne nie pas l'existence des systèmes sociaux, mais les considère comme des ensembles ouverts de relations immanentes, contingentes et partielles de croyances et de désirs collectifs. Voila pourquoi Tarde peut être considéré comme le fondateur d'une sociologie moléculaire ou microphysique.

\section{Mots-clés}

Gabriel Tarde, microsociologie, connaissance cartographique, polygénésie, ensembles sociaux

\section{Resumen}

Este artículo tiene como objetivo presentar una reconstrucción de la micro-sociología de Gabriel Tarde con el objetivo de destacar su relevancia actual. Trataré de demostrar que su distinción se basa en tomar la inmensa diversidad de pequeñas interacciones sociales como un punto de partida para el análisis tanto de relaciones cara a cara, como de instituciones en larga escala y de procesos sociales. Aquí, el campo social se describe como compuesto por múltiples propagaciones de deseos y creencias que se extienden de un individuo a otro, tomando incontables direcciones, interfiriendo entre sí, formando redes y escapando de ellas en busca de nuevas conexiones. Además trataré de demostrar que este punto de vista no niega la existencia de sistemas sociales, pero que los entiende como conjuntos abiertos de relaciones inmanentes, contingentes y relaciones parciales de creencias y deseos colectivos. Por eso Tarde puede ser considerado como el fundador de una sociología molecular o micro-física.

\section{Palabras clave}

Gabriel Tarde, Micro Sociología, Conocimiento Cartográfico, poligénesis, Conjuntos Sociales 